\title{
Design Reduirement of Pasar Besar Malang Through Site Analysis Method
}

\author{
Ade Fitriyanti Ulul Azmi, Vincentius Totok Noerwasito and Ima Defiana \\ Department of Architecture, Institut Teknologi Sepuluh Nopember, Surabaya \\ e-mail: vtonoer@arch.its.ac.id
}

\begin{abstract}
Abstrak - In discussing traditional markets, not a few are found that the market experiences a setback in existence in the community. The decline in the existence of traditional markets, one of which occurred in the Great Market of Malang with the increasing lifestyle of Malang people in harmony with technological sophistication. Pasar Besar Malang has urgency, which is experiencing 3 fires and is increasingly doubting the ability of Pasar Besar Malang to guarantee safety and comfort on the move. In addition to buyers, traders also experienced a decrease in the number due to the uneven distribution of trade transactions that caused traders to continue to suffer losses. Through the site analysis study method and the sense of place approach that is applied to the questionnaire, the potential and the possibility of utilization are explored by producing design requirements. Implementation of design requirements in the form of design aspects that discuss such as optimizing access and circulation through the transition zone. This is done in order to create a quality of space that is comfortable and able to provide sustainability for the existence of Pasar Besar Malang as a provider of needs and public space.
\end{abstract}

Kata Kunci-Pasar Besar Malang; Community Modern Market; Sense of Place; Public Space.

\section{INTRODUCTION}

$\mathrm{P}$ ASAR Besar Malang is a center of trade and economy of the people of Malang which is now not operated optimally. Of the total 3 floors, only floors 1 and 2 operate and many stalls are also found abandoned by their owners. The reason is that Malang's Great Market, which had existed during the Dutch colonial era, was deemed not to have the comfort of being able to support trade and shopping activities in the eyes of visitors. Stuffy, stifling, confusing and dark access and less hygienic impression become supporting factors for the community to switch to other providers of goods and services that are more comfortable. Pasar Besar Malang, which has begun to be neglected and whose existence is decreasing, requires treatment that can provide more value than just a provider of goods and services. This is supported by Gruen's statement as the Father of the Shopping Center cited in Sprawl Public Place: Redressing Mall (2002), states that in designing or the process of reviving old or existing shopping centers to be able to operate and survive amid the advancement of time and technology as well as improvement people's lifestyles, it is important to note 3 important points in the design process, including [1]:

1. Civic challenge

2. Economic/ social challenge

3. Design challenge.

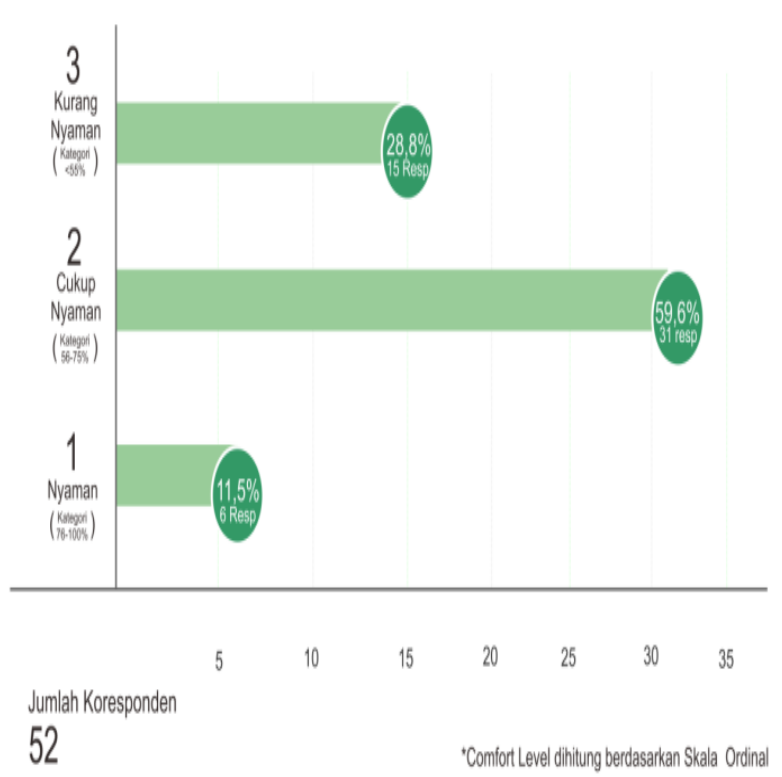

Figure. 1. Ilustrasi Grafik Diagram Tingkat Kenyamanan yang dirasakan Pengunjung dan responden Pasar Besar Malang Dan Prosentasenya.

In theory, it is the architect's responsibility to pay attention to these three things with the aim of finding a design that supports an old or existing shopping center that can continuously cover the needs and lifestyles of the community.

Through the points conveyed by Gruen, thoughts on the sustainability of shopping centers also develop. It also raises opinions related to the development of market functions or shopping centers. In developing the theory, the Market or Shopping Center is a scope that has a function as meeting the needs of goods and services. Public

Spaces and Shopping Centers are not only used as a place to meet the needs related to goods but are also utilized as a place to unwind, socialize, hangout or eat, and seek entertainment [2]

So Pasar Besar Malang as a traditional market that supplies goods and services that also has a function as a public space, should be able to accommodate social activities and have optimal comfort. In the process of creating comfort in public spaces with the main function as meeting the needs of these goods and services, a statement regarding the level of comfort and comfort needs of the Malang Pasar Pasar building was presented through the questionnaire results. The following are the results of the questionnaire regarding the level of comfort of the visitor's perception:

In figure 1 shows that from the sample of 52 questionnaire respondents, only one respondent believes that Pasar Besar 
The $6^{\text {th }}$ International Seminar on Science and Technology (ISST) 2020

July $25^{\text {th }} 2020$, Institut Teknologi Sepuluh Nopember, Surabaya, Indonesia

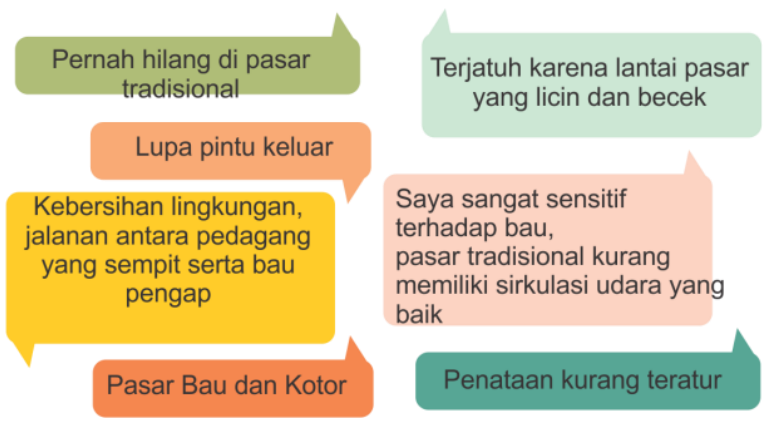

Figure. 2. Ilustrasi Grafik Range Data Faktor Penyebab Kurang Nyaman Pasar Besar Malang dalam Persepsi Pengunjung.

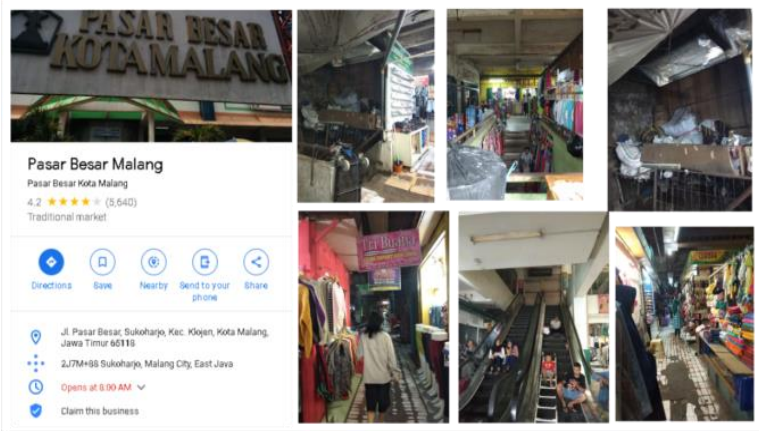

Figure. 3. Kondisi Kualitas Ruang dari Pasar Besar Malang.

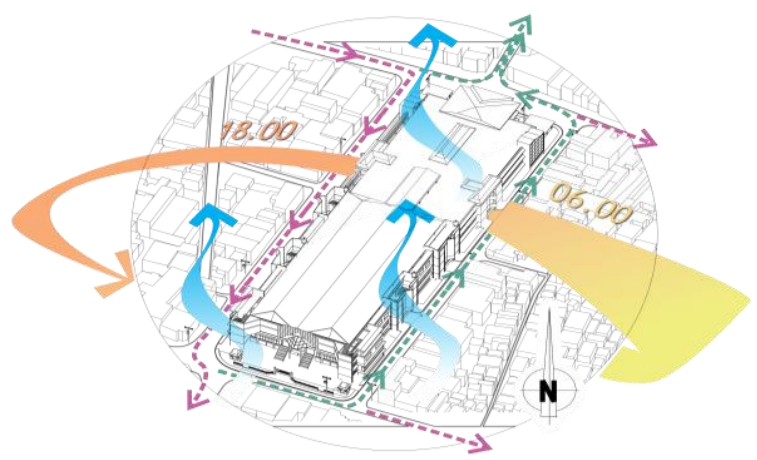

Figure. 4. Ilustrasi Analisa Eksisting Tapak Pasar Besar Malang.

Malang is comfortable in its function as a provider of goods and services, while the rest states that there are still many shortcomings of the level of comfort offered by Pasar Besar Malang. Supporting the data will also be attached to some data related to public perceptions of factors that cause the Malang Great Market to be uncomfortable, can see figure 2.

Figure 2 is the visitor data and the range of reasons for the study of the discomfort they felt when they visited Pasar Besar Malang. The reasons derived from the visitor's perception that then included are the background issues that must be resolved.

From the data above, it is mentioned several reasons for the inconvenience in terms of the quality of the room such as stuffy, smelly and dirty as well as irregular arrangement and the lack of helper markers causing confusion to forget the exit. The statement is also supported through the existing condition of Pasar Besar Malang which shows the quality of the space owned by the building, can see Figure 3 .

The study conducted in response to the problems and needs of security and the existence of the Pasar Besar Malang, was carried out by applying qualitative design methods by analyzing the potential of existing conditions. From the

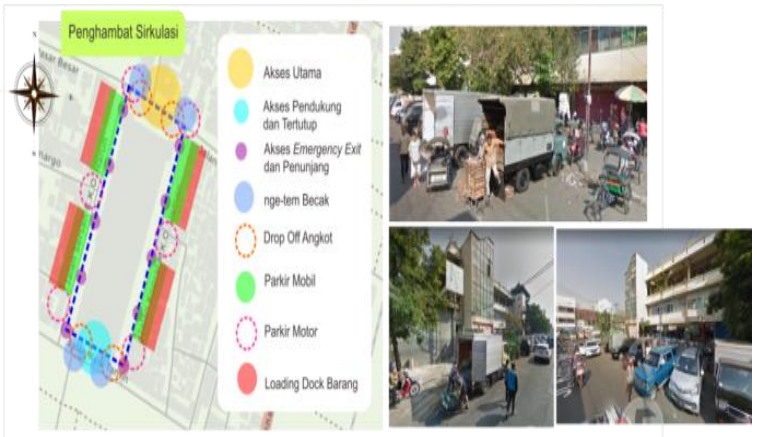

Figure. 5. Kondisi Eksisting Skeitar Tapak Pasar Besar Malang dengan Aktifitas Penghambat Sirkulasi.

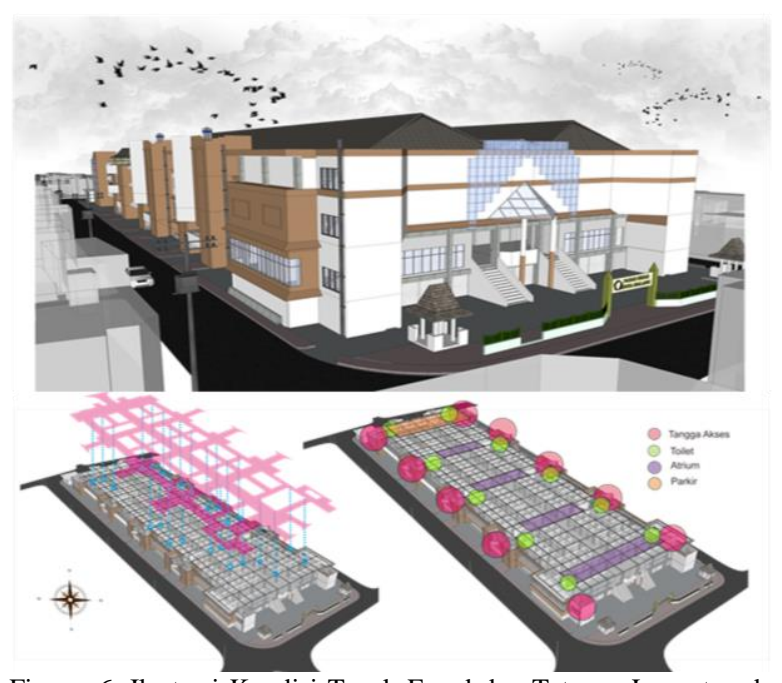

Figure. 6. Ilustrasi Kondisi Tapak Fasad dan Tatanan Layout pada Pasar Besar Malang.

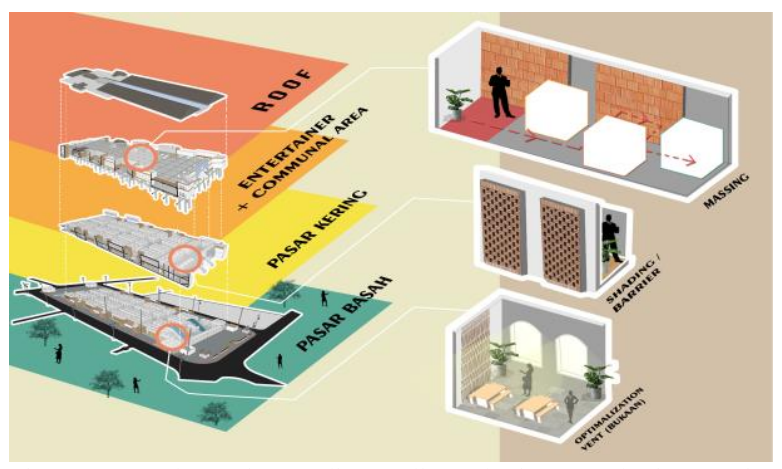

Figure. 7. Ilustrasi Analisa Climatologi (Matahari, Angin, Kelembapan dan Curah Hujan) Tapak Pasar Besar Malang.

questionnaire data that supports the problems that cause the discomfort of the Pasar Besar Malang in trading activities and social interaction, for example the stuffy feeling felt by visitors due to non-current airflow or dark areas that become negative due to lack of lighting. So the need for changes in the physical aspect of the building is optimized by examining the potential of the existing Pasar Besar Malang.

\section{METHODS}

Explained earlier, in order to overcome the design problems that have been described and supported through questionnaire data, an analysis of the existing site was carried out to provide an overview of the areas that could be addressed as well as in an effort to improve the comfort of the 


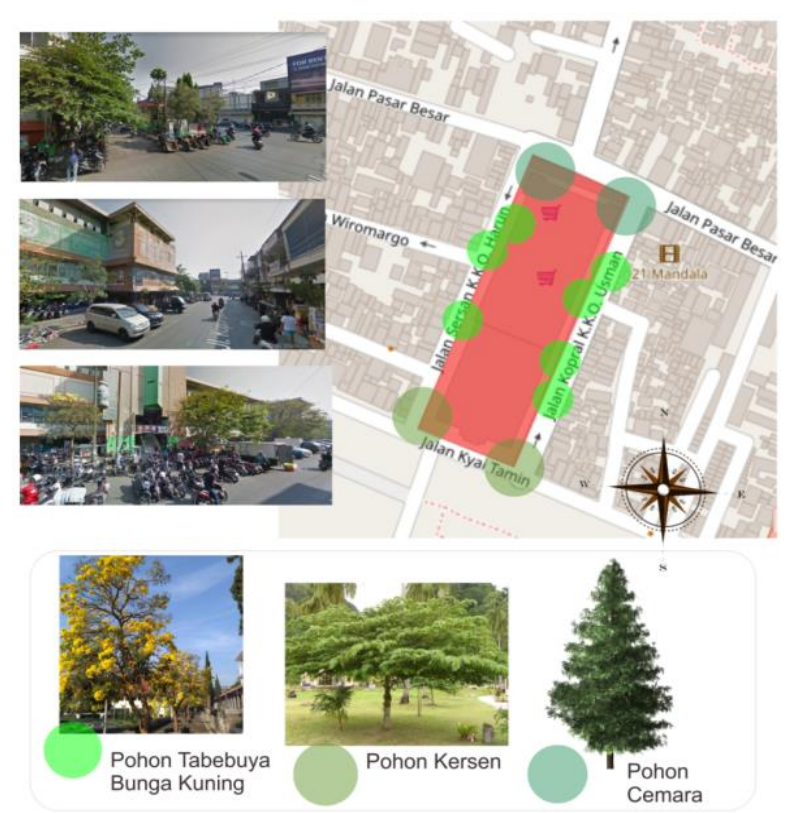

Figure. 8. Ilustrasi Analisa Vegetasi Tapak Pasar Besar Malang .

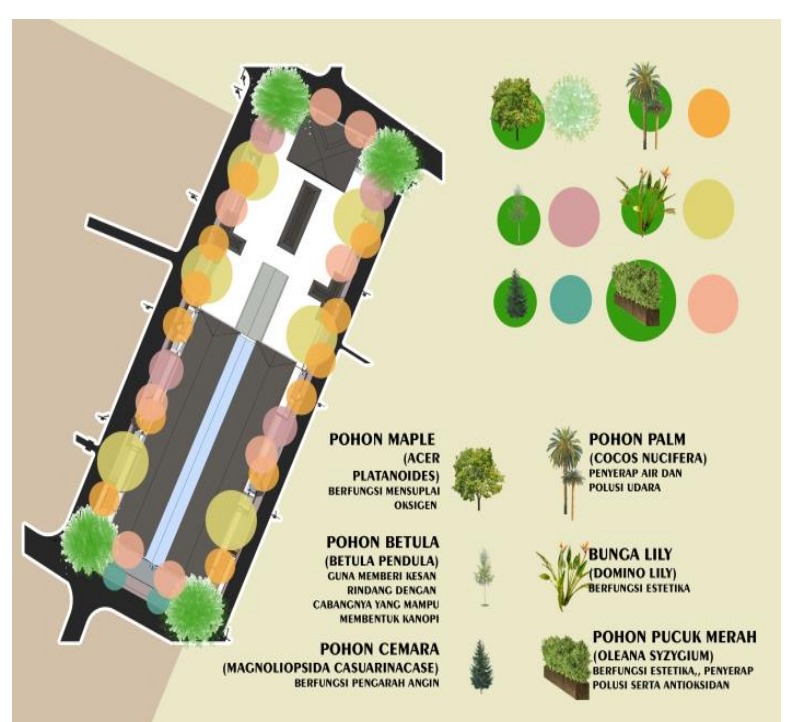

Figure. 9 Ilustrasi Analisa Vegetasi Tapak Pasar Besar Malang, Perletakan, Jenis Vegetasi dan Fungsinya.

Pasar Besar Malang. Figure 4 is the potential and analysis of the existing Pasar Besar Malang.

From the illustration of the site analysis in figure 4 , it is explained that the site of the Pasar Besar building in Malang has a direction toward the northeast. As for the wind conditions in the BMKG data for the period from February to March 2020, it shows the dominant wind direction going north from south to the Malang city area and Pasar Besar Malang. Whereas in the Sun's rotation conditions as in general, it leads from east to west, it is inversely proportional to the direction facing the building.

The potential owned by the Pasar Besar Malang building in optimizing the intensity of incoming sunlight does not experience obstacles, because the surrounding buildings do not have a significant influence in blocking sunlight from entering the Pasar Besar Malang building. And the condition of circulation around the building, is a centralized circulation with obstacles from loading dock activities and illegal

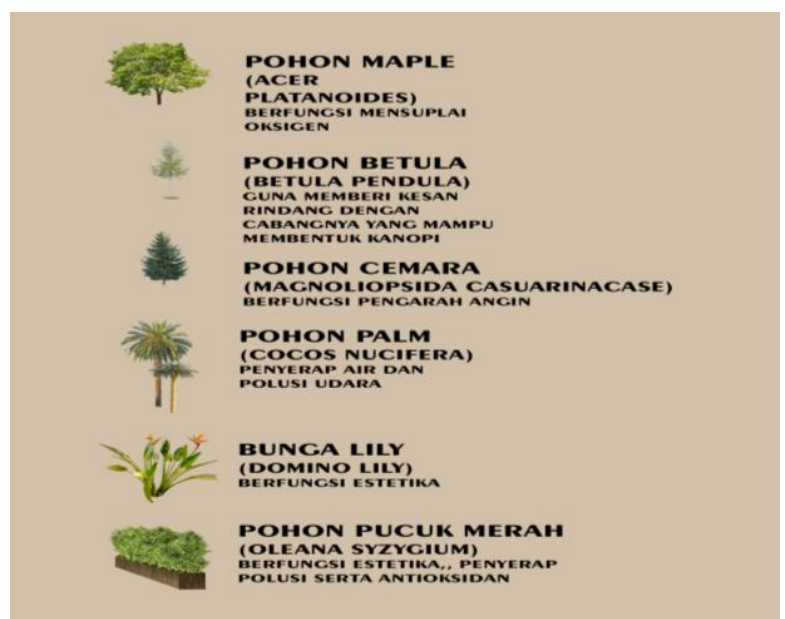

Figure. 10. Jenis Vegetasi yang dapat diterapkan pada Tapak Pasar Besar Malang.

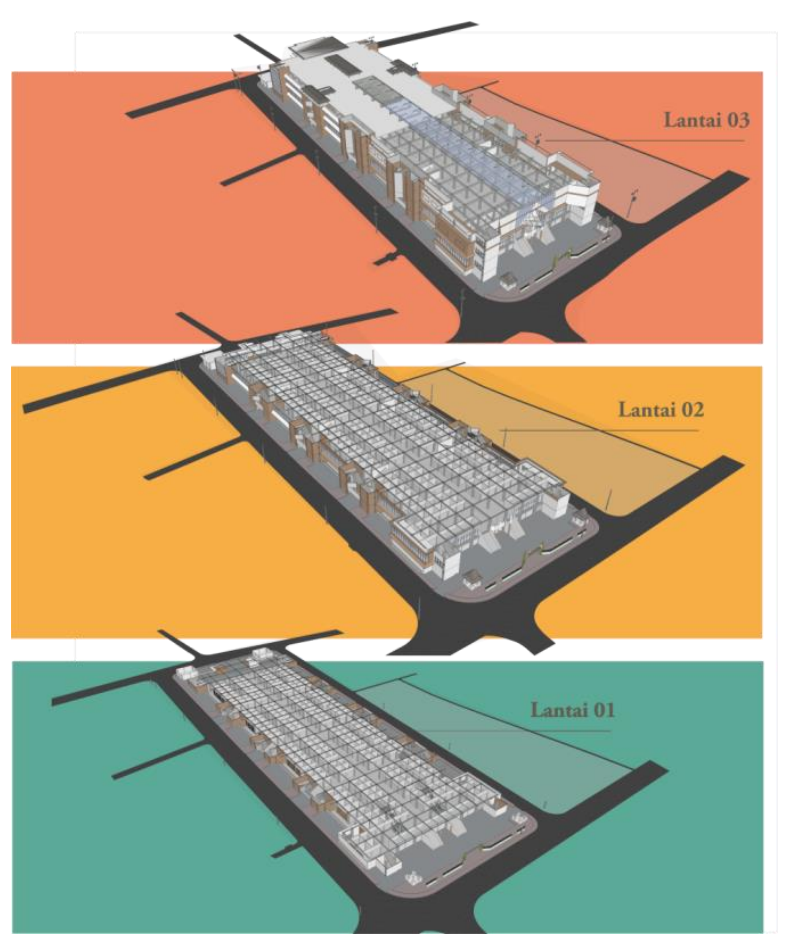

Figure. 11. Ilustrasi Kondisi Akses dan Sirkulasi Tapak Pasar Besar Malang yang memibentuk Grid dan Pattern yang sama pada Lantai 1 hingga lantai 3 .

parking on the shoulder of the road and sidewalks and public transport that is waiting for passengers, as shown in the Figure 5.

\section{A. Climatology Analysis (Sun, Wind, Humidity, Rainfall)}

Sunlight, Wind and Rainfall and Humidity are discussed together in Climatology Analysis, because it has a response that is not much different in accordance with the response needs of buildings with a humid tropical climate. As described in the figure. 3 , the potential of the site in optimizing the incoming sunlight, the wind entering the building does not experience obstacles from the surrounding buildings. However, the condition of the spatial layout and building construction which is quite rigid in terms of facade is the main obstacle in maximizing the existing potential.

The potential of the existing as well as the building formation of Pasar Besar Malang has a position perpendicular 


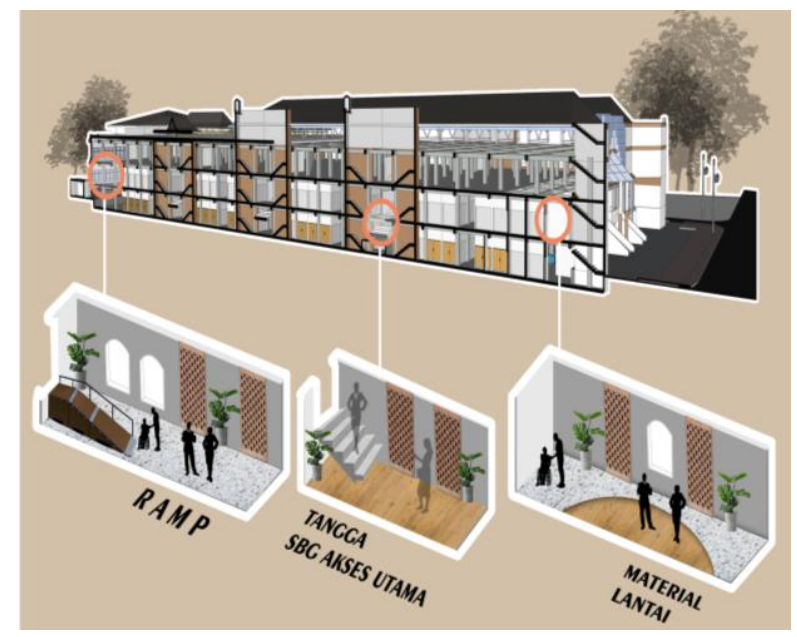

Figure. 12. Ilustrasi Analisa Akses dan Sirkulasi Tapak Pasar Besar Malang.

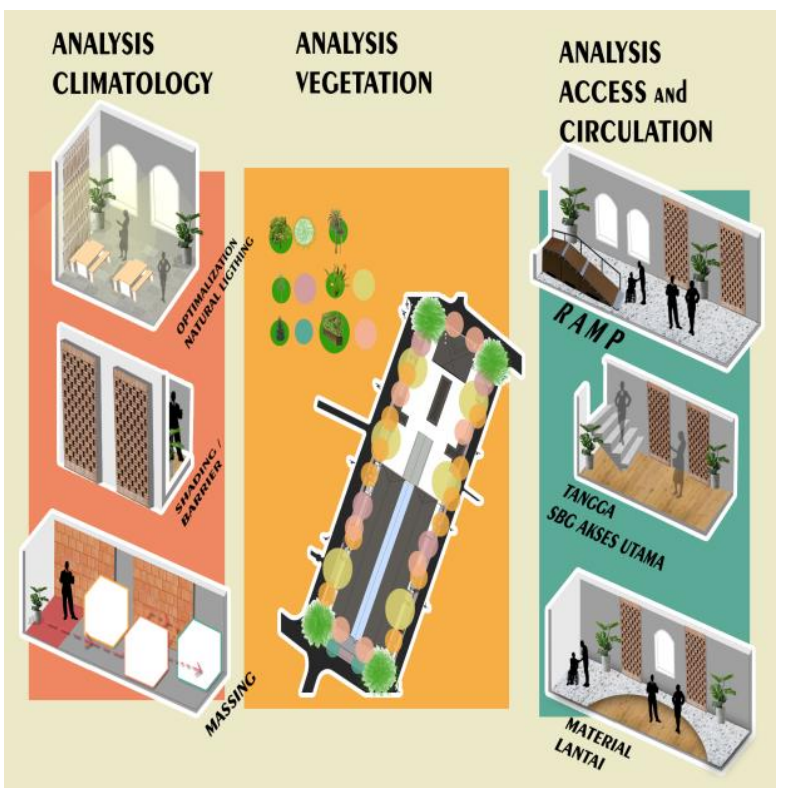

Figure. 13 Simpulan Hasil Metode Analisa Tapaka pada Pasar Besar Malang untuk Memaksimalkan Kenyamanan dan Keterikatan Ruang dengan Pengguna.

to the rotation of the sun, so the possible criteria that can be raised are by:

\section{1) Optimization of Natural Ventilation}

Changes in the formation of openings with calculations on WWR (Window to Wall Ratio) or on the amount of window openings calculated with the suitability of the area of the space will be able to give an influence on the need for airing, lighting and humidity regulation of room temperature. In an effort to optimize other natural ventilation, the aim is to give effect to the ease of air and odor exchange through the application of cross ventilation. In addition, in the nonoperating condition or at night, natural ventilation is needed [3] for the humidity of the space as well as the effect on the process of storing goods.

\section{2) Massing}

In this case, the arrangement of mass and space can provide optimization in the range of sunlight and the ease of airflow in space. It is also able to reduce the temperature humidity in the room [4].

\section{3) Shading or Barrier}

The use of shading on the building envelope can reduce the level of glare from the results of the intensity of sunlight that bounces at the openings and can reduce heat insulation from outside the building and vice versa [5]. This can be achieved by utilizing grove of trees, building structures or the addition of shading / barrier.

\section{B. Vegetation Analysis}

In the existing condition of the Pasar Besar Malang site, the existing vegetation is in an unorganized and well maintained condition, and no special space is given which causes the users to use it as an illegal waste bin. Some of the vegetation that can be found in the existing around Pasar Besar Malang, can see Figure 8.

Vegetation in the analysis gives effect to the landscape layout and appearance of a fresher design through the benefits and functions of vegetation itself. The benefits of diverse and more important vegetation namely its ability to reduce stress levels [6] in urban communities are considered suitable for application in the market function as public spaces and are able to give a flexible impression of buildings. Some criteria that can be applied in vegetation analysis include:

\section{1) Vegetation Increase}

In its existing condition, the landscape of Pasar Besar Malang has vegetation at several points but is not neatly arranged and seems unkempt. So it needs to be considered related to the growing space for vegetation so that it does not function as a negative space. Another alternative that can be applied is to add natural formations or natural elements, such as wallpaper or murals with natural or forest views. It was mentioned earlier that by giving a nuance of nature or that the element of nature to space, is able to exert a positive influence in human psychology as a main user.

\section{2) Selection of Vegetation Types and Their Functions}

In the discussion regarding the selection of vegetation it is necessary to note its suitability with the climate and soil conditions that exist in the existing. Inadequate selection of vegetation will affect the maintenance procedures and the sustainability and resilience of the vegetation.

\section{3) Placement of Vegetation}

Each vegetation has a variety of functions, so it can be adapted to the needs of each different existing condition. Vegetation with a type that is able to absorb moisture and pollution from dirty air such as cigarette smoke and unpleasant odors is recommended to be placed in the interior area while vegetation with the function of antioxidants, noise absorbers, shade, wind directors and water absorbent can be placed in the landscape area of Pasar Besar Malang building

\section{Access dan Sirculation Analysis}

Access and circulation are hampered around the Pasar Besar building in Malang, due to the fact that parking is not managed and the loading dock area is right inside the Market building. So that the congestion of vehicles that are supported by the existence of city public transportation that is waiting for passengers is getting worse. In an effort to reduce congestion outside access it is necessary to add parking 
The $6^{\text {th }}$ International Seminar on Science and Technology (ISST) 2020

July $25^{\text {th }} 2020$, Institut Teknologi Sepuluh Nopember, Surabaya, Indonesia

facilities and loading dock as well as clear drop offs.

In figure 11, it is an illustration of site conditions related to access and circulation of the Pasar Besar Malang which has a spatial arrangement and layout forming a grid (intersecting axes) and a similar pattern from floor 1 to floor 3 . This also gives an effect on barriers to light range the sun and also natural ventilation [7] to be felt evenly throughout the space.

The unclear and undirected existing circulation confuses visitors and causes visitors to get lost, and is added to the issue of visitor perceptions that the floor is quite slippery, capable of causing injury and endangering users. Then the following criteria appear:

\section{1) Easy to access (Additional Ramp)}

Ease of Access to Traditional Markets that are able to be accessed by all groups of people, including ease of wheelchair users, disabilities and beginners, crutch users and easy access to stroller for toddlers. This can be applied through the addition of a ramp / travelator.

\section{2) Stairs as the main access.}

In field conditions. Pasar Besar Malang has an escalator connecting floors 2 and 3 , but it is not operated. The selection of stairs as the main access in order to provide easy access with a relaxed impression by enjoying the shopping view, is chosen stairs that are quite gentle so that it is not heavy to access.

\section{3) Safe Material Selection.}

It was stated in the results of the questionnaire that, there are parts of the floor that are quite slippery and capable of causing injury to users. So that the application of floor materials such as tile granitte is efficient enough to be applied. The application of material is also able to give the impression of being relaxed and clean in the process of creating Pasar Besar Malang as a provider of goods and services as well as public space. The advantages of applying different materials will also facilitate the maintenance and operational processes in the Pasar Besar Malang building. In this case, it is recommended to apply granite tile material because it has the impression of natural stone nuances and is not slippery like ceramics in general, and is also easy to maintain.

\section{RESULT AND DISCUSSION}

From the analysis of the Great Malang Market site and the criteria that emerged through the issue that was responded to in order to improve comfort, produced :

1. In the existing condition of the building of Pasar Besar Malang tend to be rigid with massing that is less flexible, so that the quality of the resulting space is not so comfortable to be felt by the users. From the formation and layout of the layout now has a less optimal airflow and lighting, so that climatological analysis appears design criteria that can be applied by optimizing airflow and natural lighting to be able to enter the space through the mass / layout order, optimizing openings and coating materials. on the sheath in the form of shading / barrier.

2. Comfort can be applied through physical and nonphysical or psychological. One convenience that can add to the pain between the user and the place is the addition of vegetation or natural elements. This is applied in vegetation analysis that is tailored to the needs and functions. From the existing conditions in the Pasar Besar Malang, the vegetation around the building is still poorly organized and well maintained and no special land is provided and is sometimes used as a negative space such as an illegal garbage dump. So that the arrangement and placement of vegetation must be considered, because it can provide benefits and affect the stress release of users.

3. With the function of the market as a public space that is accessed by every society and its main function as a provider of goods and services, ease of access needs to be considered in improving comfort.

\section{REFERENCES}

[1] National Endowment for The Arts. Sprawl Public Space : RedressingThe Mall. New York : Princeton Architectural Press. 2002. Pg. 10-11

[2] Kliment, S., \& Barr, V. Building Type Basics for Retail and MixedUse Facilities. USA: Jerde Partnership International. 2004. Cp 01- Pg 1-3.

[3] Defiana , Ima et al, Night Ventilation At Courtyard Housing Estate In Warm Humid Tropic For Sustainable Environment. UK : IOP Conf. Ser.: Earth Environ. Sci. 126 012029, 2018. Pg. 3.

[4] DeKay, Mark, Brown G.Z, Sun, Wind \& Light: Architectural Design Strategies Third Edition. Canada : John Willey \& Sonsm Inc. 2014. Pg 15-17.

[5] D. K. Ching. Architecture, Form, Space \& Order : Third Edition. New Jersey : John Willey \& Sons, Inc. 2007. Pg. 176.

[6] Kellert, Stephen R., Judith and Martin Mador, Biophilic Design, USA : John Willey \& Sons, Inc. 2008, Pg 325-334.

[7] DeKay, Mark, Brown G.Z, Sun, Wind \& Light: Architectural Design Strategies Third Edition. Canada : John Willey \& Sonsm Inc. 2014. 